University of Nebraska - Lincoln

DigitalCommons@University of Nebraska - Lincoln

1988

\title{
Patterns of Resource Use by a Drosophilid (Diptera) Leaf Miner on a Native Crucifer
}

\author{
S. K. Collinge \\ Harvard University \\ Svata M. Louda \\ University of Nebraska - Lincoln, slouda1@unl.edu
}

Follow this and additional works at: https://digitalcommons.unl.edu/bioscifacpub

Part of the Life Sciences Commons

Collinge, S. K. and Louda, Svata M., "Patterns of Resource Use by a Drosophilid (Diptera) Leaf Miner on a Native Crucifer" (1988). Faculty Publications in the Biological Sciences. 92.

https://digitalcommons.unl.edu/bioscifacpub/92

This Article is brought to you for free and open access by the Papers in the Biological Sciences at DigitalCommons@University of Nebraska - Lincoln. It has been accepted for inclusion in Faculty Publications in the Biological Sciences by an authorized administrator of DigitalCommons@University of Nebraska - Lincoln. 


\title{
Patterns of Resource Use by a Drosophilid (Diptera) Leaf Miner on a Native Crucifer
}

\author{
S. K. COLLINGE ${ }^{1}$ AND S. M. LOUDA ${ }^{2}$ \\ School of Biological Sciences, University of Nebraska, Lincoln, Nebraska 68588 \\ Rocky Mountain Biological Laboratory, Gothic, Colorado 81224
}

\begin{abstract}
Ann. Entomol. Soc. Am. 81(5): 733-741 (1988)
ABSTRACT Distribution and damage of Scaptomyza nigrita Wheeler on its host (bittercress, Cardamine cordifolia A. Gray), a native perennial crucifer, were examined over two growing seasons in relation to leaf position. Concentrations of defensive compounds (glucosinolates) and of nutritive compounds (total nitrogen, free amino acids, soluble carbohydrates) were also examined. The fly-host plant relationship was studied in sun and shade habitats at two sites. Oviposition and leaf-mining damage were concentrated on the lower central leaves of a stem in both habitats. These mature leaves have lower glucosinolate concentrations than new leaves. Adult densities and larval feeding damage were consistently and significantly greater on plants in the sun than on those in the shade. Higher S. nigrita densities in the sun habitat and slightly higher soluble carbohydrate concentrations in sun leaves at the beginning of the growing season, rather than variation in defensive glucosinolate levels, are the most likely mechanisms determining higher levels of leaf mining on host plants in the sun habitat.
\end{abstract}

KEY WORDS Insecta, plant-insect interaction, leaf miner, herbivory

SPATIAL PATTERNS of insect occurrence and leaf damage are often associated with variation in plant quality (White 1969-1984, Mooney \& Chu 1974, Rosenthal \& Janzen 1979, Mattson 1980, Crawley 1983, Denno \& McClure 1983, Prestidge \& McNeill 1983) or in environmental conditions (Huffaker \& Kennett 1959; Harper 1969; Coley 1983; Louda \& Rodman 1983a,b; Louda 1986; MacGarvin et al. 1986; Louda et al. 1987). Leaf miners show spatial patterns in distribution (e.g., Condrashoff 1964, Miller 1973, Faeth et al. 1981, MacGarvin et al. 1986) and are of particular interest because they are often abundant and can affect growth and reproduction of both native and cultivated species (Louda 1984, University of California Statewide IPM Project 1985)

Adults of endophagous insects such as leaf miners choose their larval feeding site by choosing oviposition sites (Hering 1951, Miller 1973, Whitfield et al. 1985). Selective pressures should result in females ovipositing in leaves which promote increased larval development and survival (Mitchell 1975, Wiren \& Larsson 1984, Larsson et al. 1986; but see Chew 1977, Wolfson 1982). Therefore, larval occurrence and damage should reflect qualitative and quantitative differences in plant quality detectable by the ovipositing female (Chew 1977, Rausher 1979). Adult females of some leaf-mining species appear to sample plant quality. For ex-

\footnotetext{
${ }^{1}$ Current address: Museum of Comparative Zoology, Harvard University, Cambridge, Mass. 02138.

${ }^{2}$ Address correspondence to S. M. Louda, School of Biological Sciences, University of Nebraska, Lincoln, Nebr. 68588.
}

ample, agromyzid females puncture holes in the leaf cells with their ovipositor and then "test" the sap (Hering 1951, Dureseau \& Jeandel 1977); it is not clear whether they are merely sampling the leaf tissue or are actually feeding. However, mandibular chemoreceptors exist in many insect species, including dipteran crucivores, which are sensitive to characteristic host plant chemicals and primary nutrients (Chapman 1982).

Most information on native plant hosts is for leaf miners of woody plants (e.g., Condrashoff 1964, Faeth et al. 1981, Connor et al., 1983, Faeth 1985, Bultman \& Faeth 1988). Consequently, we studied an indigenous leaf miner utilizing an herbaceous native plant on which we have background information.

Previous work on the insect-bittercress interaction has demonstrated that total insect herbivore load on bittercress is greater on sun than on shade plants (Louda \& Rodman 1983a,b; Louda in press); increases as glucosinolate concentrations decrease (Louda \& Rodman 1983b); increases as the watersoluble (nitrate) nitrogen concentrations in leaves increase (Louda 1986, in press); reduces plant vertical growth, leaf development, and seed reproductive success (Louda 1984); and increases on experimentally water-stressed plants in the shade (Louda 1986) or on experimentally shaded plants in the sun (Collinge 1987). However, no information is available on the response of the leaf miner, one of the important herbivores on bittercress, either to environmental variation or to differences in host plant quality.

Consequently, we considered three questions for 
the interaction of the crucifer-feeding leaf miner, Scaptomyza nigrita Wheeler, with its native host plant, bittercress (Cardamine cordifolia A. Gray) (Cruciferae). First, what is the distribution of leaf miners within and between plants in adjacent sun and shade habitats? Second, is the distribution of leaf miners within an individual plant correlated with the known pattern of secondary compound variation within the host plant? Third, are differences in the amount of damage inflicted by leaf miners between sun and shade habitats related to differences in plant quality between the two habitats, and, if so, how?

\section{Materials and Methods}

Site and Host Plant. The study was conducted at the Rocky Mountain Biological Laboratory in Gothic, Colo., $9.6 \mathrm{~km}$ northwest of Crested Butte, Gunnison County, during 1985 and 1986. The vegetation is montane and typical for the area (Langenheim 1955, 1962). We used two specific study sites-Site 1 is at $3,040 \mathrm{~m}, 1.2 \mathrm{~km}$ north of Gothic along Copper Creek ("Main Site" of Louda \& Rodman 1983a,b). Site 2 is at 2,985 m, located $3 \mathrm{~km}$ west of Gothic on Forest Service Trail 401 ("ABP" of Collinge 1987). Both sites were large ( 30 by $10 \mathrm{~m}$ ) snow-melt seep areas with dense (355 stems $/ \mathrm{m}^{2}$ ) stands of bittercress.

Bittercress is a common perennial crucifer that grows in wet, often shaded areas along streams (Harrington 1954) or in large glacial seeps that remain moist throughout the summer (unpublished data). With sufficient soil moisture, bittercress grows in the sun as well as in the shade of willows, Salix spp., or spruce, Picea engelmani Parry (Chew 1977; Louda \& Rodman 1983a,b). This native herbaceous plant begins flowering in late June and typically sets seed in August or early September (Louda \& Rodman 1983a). Bittercress plants also reproduce vegetatively, and large clones may contain $\cong 50$ ramets (unpublished data).

Leaf Miner. S. nigrita is one of the most common insects that feed on the leaves of bittercress in the study region (S.M.L., unpublished data). The details of the life history can be summarized as follows (Collinge 1987). Females oviposit in late May and early June, soon after snow melt. Larvae begin feeding in early to mid-June and feed for 2 $3 \mathrm{wk}$, forming a linear mine. Pupation usually occurs within the leaf mine. Early instars collected in the field and reared in the laboratory pupate in $16 \mathrm{~d}$ on the average $(\bar{x}=16.2$; range, $6-25)$. Adults generally emerge $10 \mathrm{~d}$ later $(\bar{x}=9.2$; range, $6-15)$. This species is probably univoltine at this elevation (Collinge 1987).

Procedures. At each habitat, we measured two physical parameters known to be critical to insect behavior, thermoregulation, and development (Clark 1967, Bursell 1974)—photosynthetically active radiation (PAR) and seasonal temperature accumulation. PAR intensities were taken in sun and in adjacent shade habitats using a PAR sensor (LiCor 190S, Li-Cor, Lincoln, Nebr.). Representative readings were taken between 1100 and 1300 hours (MST) on two dates during the growing season at Site 2 (5 June and 16 August 1986, $n=10$ per habitat). Accumulation of temperature differences between sun and shade habitats was measured at Site 2 using biophenometers (Growing Degree-Day Accumulator: Omnidata, Logan, Utah). One unit was placed in each habitat and recorded ambient temperature every $10 \mathrm{~min}$ (26 June to 6 August 1986).

To sample adults, yellow paper rectangles $(6.5$ by $11.5 \mathrm{~cm}$ ) were spread with Tangletrap (Jones et al. 1986) placed horizontally on a wire stake 35 $\mathrm{cm}$ above ground next to bittercress ramets and left for $24 \mathrm{~h}$ ( $n=5$ per habitat). Because oviposition activity is highest early in June (Collinge 1987), we sampled adult densities with sticky traps in early June (Site 1 on 4 and 6 June 1986; Site 2 on 3, 5 , and 7 June 1986). We also observed adult densities in sun and in shade habitats on large clones (between 27 May and 7 June 1986, Site 2; 10-min observations, $n=6$ per habitat).

We collected leaf samples of $C$. cordifolia at 3-wk intervals from both sites in 1985 and 1986 to assess egg loads and feeding damage by larvae. Distribution of larvae on leaves is directly correlated with egg distribution (S.K.C., unpublished data). Clones of the same height and reproductive condition were chosen from both habitats. Fifteen ramets within clones were selected randomly and cut below the lowest cauline leaf. On these ramets, we measured plant development and reproductive status ( $n=15$ per habitat per date). In addition, for those leaves containing leaf mines, we recorded leaf position, condition (green, yellow, dead), and length; number of mines, when distinct; and total leaf area mined per leaf. The area mined was measured by comparing the damaged area with a $\mathrm{mm}^{2}$ grid (e.g., Louda 1984). We could not record the number of leaf mines late in the season because the mines coalesced.

Plants were collected for chemical analysis on three dates ( 7 and 30 June, 25 July 1986). Ramets were cut below the lowest leaf (7-15 ramets per sample; $n=5$ samples per habitat per date), placed in a plastic bag partly filled with cold water, and returned to the laboratory. Samples were completely processed within $4 \mathrm{~h}$. All leaves were removed from the ramets, weighed, and preserved. Material to be analyzed for total nitrogen, free amino acids, and total nonstructural (i.e., soluble) carbohydrates were immediately frozen in liquid nitrogen, lyophilized for $48 \mathrm{~h}$, then stored in sealed plastic bags with desiccant until the analysis. Material to be analyzed for the mustard oil precursor (glucosinolate) concentrations were placed in boiling 70\% methanol for 5-10 min, then stored in sealed jars until analysis (Rodman 1978; Louda \& Rodman 1983a,b). Total nitrogen content was determined on dried ground leaf material (Wiley 
mill, 20 mesh) using a standard Kjeldahl technique (UNL Agronomy Department, Association of Official Analytical Chemists 1975). Total free amino acids were assayed by first crushing $100 \mathrm{mg}$ of ground leaf material in a small amount of liquid nitrogen, then boiling the crushed material for 3$4 \mathrm{~s}$ in $75 \%$ ethanol to extract the soluble nitrogen compounds (Atkins \& Canvin [1971], as modified by Holaday \& Chollet [1983]). This solution was transferred to an 8-cm Buchner funnel and filtered through Whatman No. 1 filter paper. Total free amino acid concentration in this extract was determined using the ninhydrin reagent (Moore \& Stein 1954). Total nonstructural carbohydrate concentrations were analyzed by the University of Alaska Palmer Laboratory, using the methods of Smith (1969). Isothiocyanate-yielding glucosinolate concentrations were determined at the University of California, Los Angeles by A. Gonzalez and C. Wisdom, using high-performance liquid chromatography (Minchinton et al. 1982).

Analysis. PAR values and adult fly densities in sun and shade were analyzed using Student's $t$ test. The distribution of leaf-mining damage on leaves within stems was quantified as the proportion of the total leaves mined in each position for 10 different leaf position classes. These proportions were tested against a uniform distribution using a $\chi^{2}$ test to see if the leaves in each position were equally vulnerable.

Frequency of damage was quantified as the mean number of mined leaves on a ramet. Amount of damage referred to the mean area $\left(\mathrm{mm}^{2}\right)$ mined per leaf. Damage to dead or missing leaves on the last two sampling dates was estimated. We used the probability of a leaf in that position being mined and the mean amount of leaf area mined for a leaf in that position on the previous sampling date. This underestimates the amount of damage, because it does not include any damage accumulated from the last sampling date to the date of leaf mortality.

Differences in damage between sun and shade were analyzed separately for each sampling date using one-way analysis of variance (ANOVA, SAS Institute 1985). Repeated-measures ANOVA was used to compare the patterns of accumulation of damage in sun and shade during the growing season (Winer 1971). Values for total leaf area mined were square-root transformed to normalize their distribution.

Four chemical analyses were conducted on preserved leaf material - total nitrogen, total free amino acids, total nonstructural carbohydrates, and glucosinolates. Plant chemical concentrations were compared statistically by rank-ordering the observations and then subjecting each group to a one-way ANOVA (SAS Institute 1985). This is equivalent to the nonparametric Kruskal-Wallis $k$-sample test (Quade 1966).

Voucher specimens of Scaptomyza nigrita have been placed in the American Museum of Natural History, New York.
Table 1. Distribution of temperature accumulation near bittercress plants in sun-exposed and adjacent willowshaded habitats at Site 2, 26 June-6 August 1986

\begin{tabular}{crc}
\hline \multirow{2}{*}{ Temperature range $\left({ }^{\circ} \mathrm{C}\right)$} & \multicolumn{2}{c}{$\%$ of total time } \\
\cline { 2 - 3 } & Sun & Shade \\
\hline $0-1.5$ & 5.2 & 15.1 \\
$1.5-9.0$ & 51.6 & 47.2 \\
$9.0-16.0$ & 31.5 & 30.8 \\
$16.0-23.5$ & 11.4 & 6.3 \\
$23.5-30.5$ & 0.1 & 0.4 \\
\hline
\end{tabular}

\section{Results}

As expected, light intensity and temperature accumulation were higher in the sun than in the shade. For example, early-afternoon PAR values were significantly greater in sun than in shade on both dates (overcast sun $\bar{x}=908.3 \mu \mathrm{E} / \mathrm{m}^{2}$ per $\mathrm{s}$, $\mathrm{SE}=32.82$; shade $\bar{x}=638.5 \mu \mathrm{E} / \mathrm{m}^{2}$ per $\mathrm{s}, \mathrm{SE}=$ 26.37, with $F_{1,24}=57.5, P<0.05$ on 5 June; and, sun $\bar{x}=1,826.0 \mu \mathrm{E} / \mathrm{m}^{2}$ per $\mathrm{s}, \mathrm{SE}=115.52$; shade $\bar{x}=184.3 \mu \mathrm{E} / \mathrm{m}^{2}$ per $\mathrm{s}$, with $F_{1,17}=598.34, P<$ 0.05 on 16 August 1986). Also, sun-exposed areas remained at higher temperatures for a longer time than did shaded areas; temperatures remained cool (between 0 and $1.5^{\circ} \mathrm{C}$ ) more than $15 \%$ of the time in the shade but only $5 \%$ of the total time in the sun (Table 1).

Adult flies were more abundant and more active on plants in sun than on those in shade. In the timed observations between 27 May and 7 June (Site 2), the average number of adults observed per 10 -min period was significantly greater in the sun than in the shade ( $\operatorname{sun} \bar{x}=4.2, \mathrm{SE}=1.22$; shade $\bar{x}=0.6, \mathrm{SE}=0.2 ; t=2.82, \mathrm{df}=5.3, P<0.05)$. In addition, adult densities in sticky traps were significantly greater in sun than in shade at both sites $(\operatorname{sun} \bar{x}=5.4, \mathrm{SE}=0.9$; shade $\bar{x}=2.4, \mathrm{SE}=$ 0.4 at Site $1 ; t=2.98$, df $=11.8, P<0.05, n=10$ traps per habitat; sun $\bar{x}=1.4, \mathrm{SE}=0.3$; shade $\bar{x}=$ $0.1, \mathrm{SE}=0.1$ at Site $2 ; t=4.07, \mathrm{df}=15.2, P<$ $0.005, n=15$ traps per habitat).

Host plants in the willow shade appeared to be larger in both sampling years. Plants in the shade were taller, produced longer inflorescences, and had a longer fifth leaf than did those plants growing in sunny areas (Table 2). In addition, shade plants at Site 1 had more cauline leaves per ramet than did sun plants (Table 2). Leaves in the shade were about half as thick as those in the sun (S.M.L., unpublished data).

Shade plants had significantly higher concentrations of total nitrogen than those in the sun on the first two sampling dates in 1986 (Table 3). However, there were no statistically significant differences in total free amino acid concentrations between sun and shade (Table 3). However, the trend in free amino acid concentrations was similar to that of total nitrogen-higher in shade than sun on 

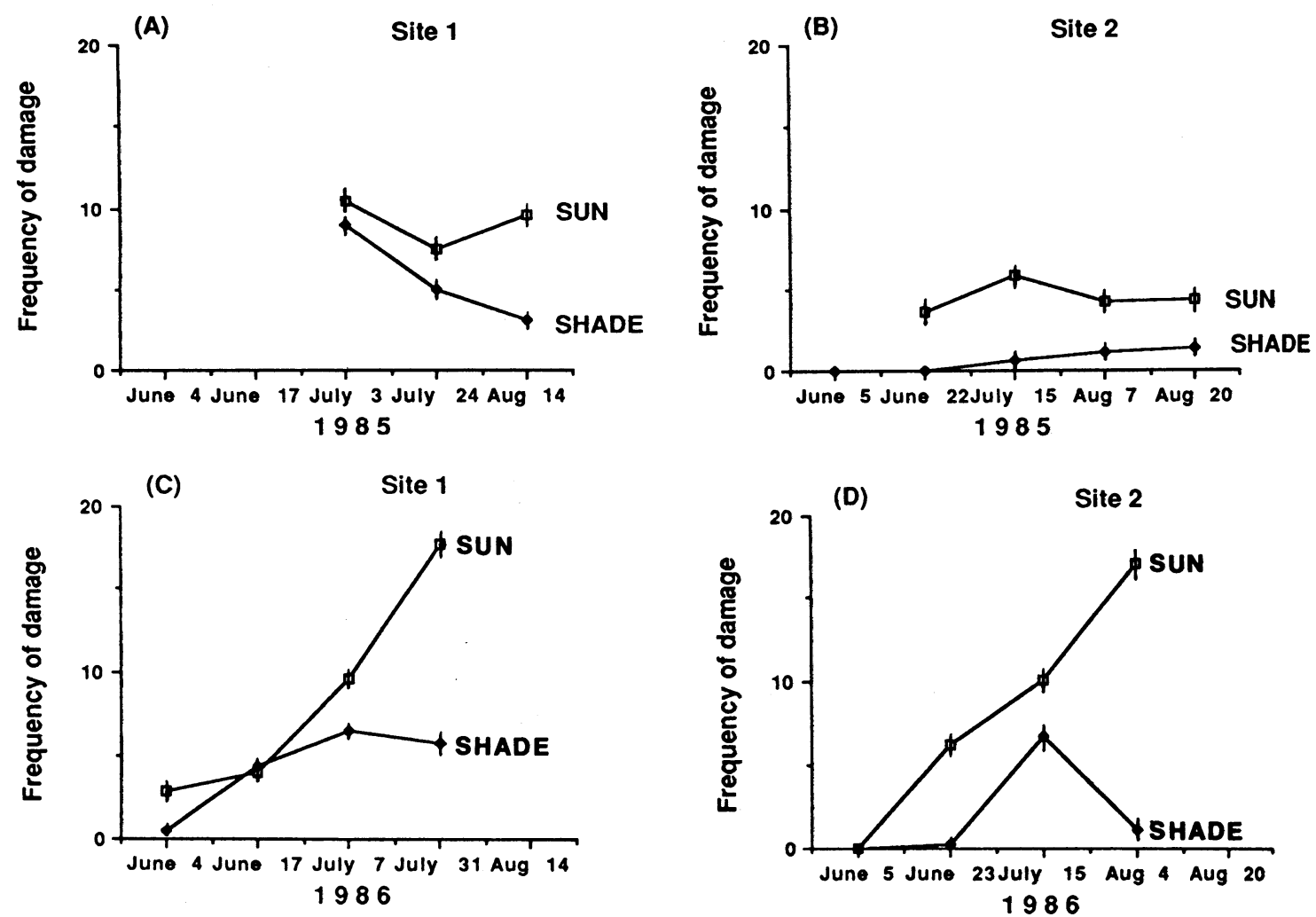

Fig. 1. Frequency of leaf-mining damage on C. cordifolia, measured as the number of mined leaves per stem, in sun-exposed versus adjacent shaded habitats in 1985 and 1986. (A) and (C), Site 1; (B) and (D), Site 2. Open squares $(\square)$, sun; closed diamonds $(\bullet)$, shade. Vertical lines are standard error bars. Differences between the means on the final sampling dates for each site and year are significant (ANOVA, $P<0.05$ ).

the first two sampling dates and decreasing over the growing season (Table 3).

There was a temporal trend in the sun in the proportion of total amino acids represented by betaamino acids such as proline. These amino acid con- centrations were initially lower in the sun than in shade, and they increased significantly during the season (Table 3).

Soluble carbohydrate concentrations were higher in the sun plants on the first two dates. On the last

Table 2. Characteristics of $C$. cordifolia plants $(\bar{x}, \mathbf{S E})$ in sun and in shade habitats

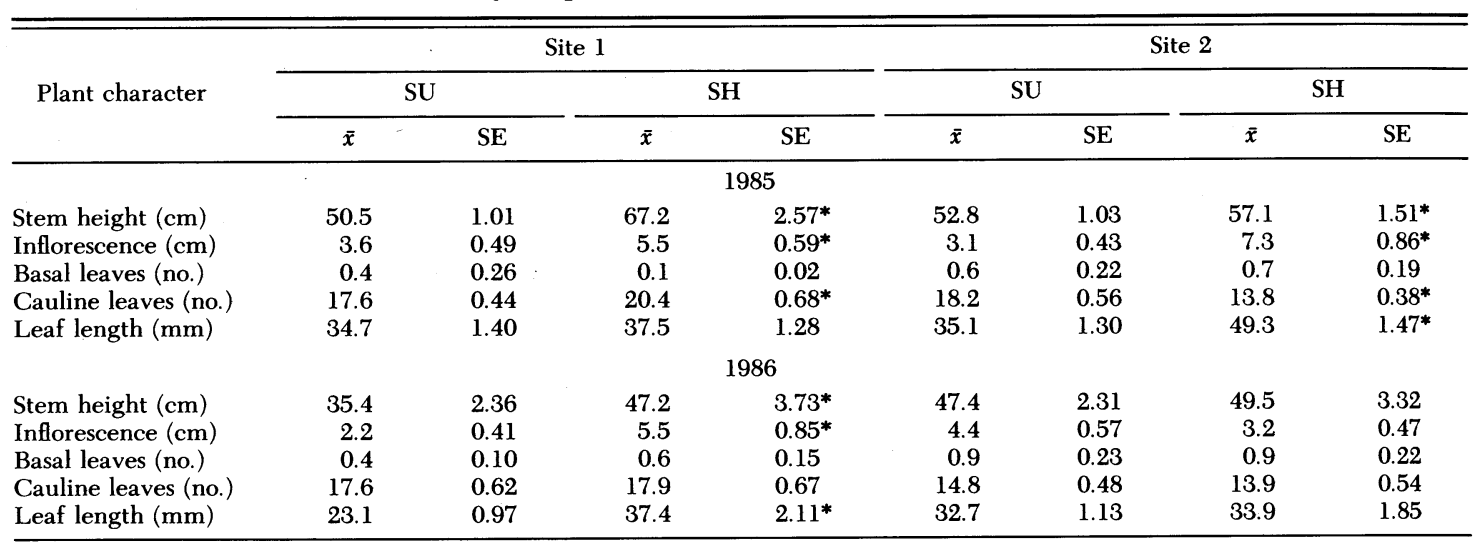

Site 1, “Main Site" of Louda \& Rodman (1983a,b), 1.2 km north of Gothic along Copper Creek (3,040 m); Site 2, “ABP” of Collinge (1987), $3 \mathrm{~km}$ northwest of Gothic on Forest Service Trail $401(2,985 \mathrm{~m})$

$a *, P<0.05$, ANOVA. 
date the pattern was reversed (Table 3), probably due to a phenological "lag" in the shade plants.

Total isothiocyanate-yielding glucosinolate concentrations of plants from adjacent sun and shade habitats were highly variable and not significantly different between habitats (Table 3), although they appeared to be slightly higher in the sun.

The frequency of leaves mined on a stem was greater on plants in the sun than on plants in adjacent shade (Fig. 1A-D). On the final sampling dates in both years, the difference was significant at both sites (ANOVA, $P<0.05$ ). Interestingly, leaf-mining damage did not accumulate similarly in the sun and shade habitats at either study site in either year (repeated-measures ANOVA, $P<$ 0.05 , Fig. 1A-D). Also, the absolute number of leaves mined on a stem was higher in 1986.

The amount of leaf area damaged by the leaf miners by the final sampling date was significantly greater in sun than in shade at both sites in both years (ANOVA, square-root transformed data, $P<$ 0.05 ). In 1985, area damaged accumulated similarly in sun and in shade over the growing season (repeated-measures ANOVA, $P>0.10$, Fig. 2A and $B)$. In 1986, the accumulation of damaged area was approximately equal in sun and in shade until late July, when it declined sharply in the shade leaves (repeated-measures ANOVA, $P<0.05$, Fig. $2 \mathrm{C}$ and $\mathrm{D}$ ). All eight seasonal curves show an increase in the leaf area damaged by leaf miners up to mid-July or early August. Five of the eight cumulative curves then decline (Fig. 1 and 2 ), suggesting that our estimate of leaf-miner damage to missing or dead leaves was too conservative.

Most leaves mined occur on the lower two-thirds of the stems (Fig. 3A-D). Generally, the youngest leaves (positions 13-16 and higher) tended to have less damage in both sun and shade habitats at both study sites (Fig. 3A-D). All within-plant distributions deviated significantly from uniform distributions ( $\chi^{2}$ test, $\left.P<0.05\right)$.

\section{Discussion}

Between Habitats. Our results present a clear, consistent pattern of leaf-miner attack in relation to physical environmental variation between habitats and associated differences in plant quality. The frequency of attack, as estimated by the number of mined leaves per ramet (Fig. 1), and the amount of leaf area damaged (Fig. 2), were greater in sunny areas than in adjacent shaded habitats during both of the seasons studied. The cumulative area consumed by leaf miners in the sun at these sites is high, approaching $75 \%$ of total leaf area by the end of the season (Fig. 2A-D). Levels even lower than these significantly depress bittercress growth and seed production (Louda 1984). Consistently higher insect-herbivore pressure in the sun contributes significantly to the compression of the realized distribution of bittercress to the shade

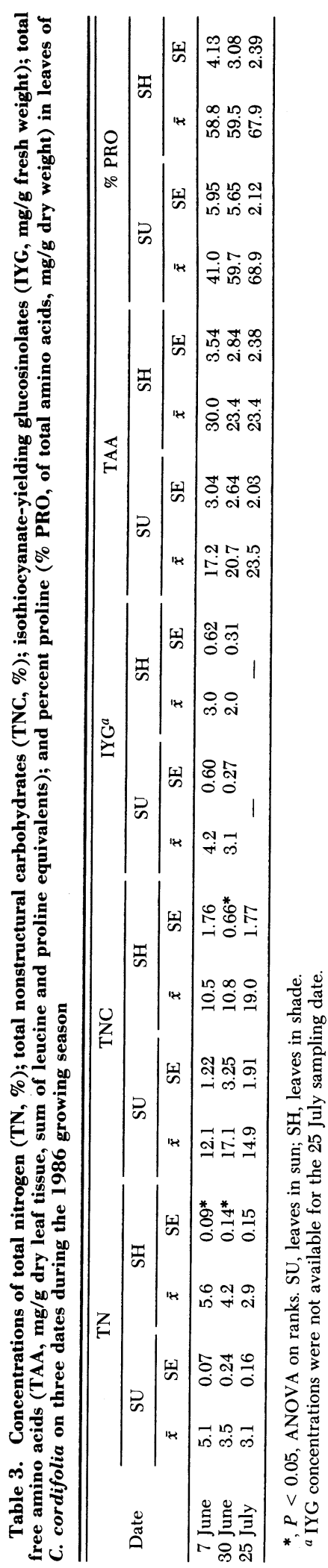


(A)

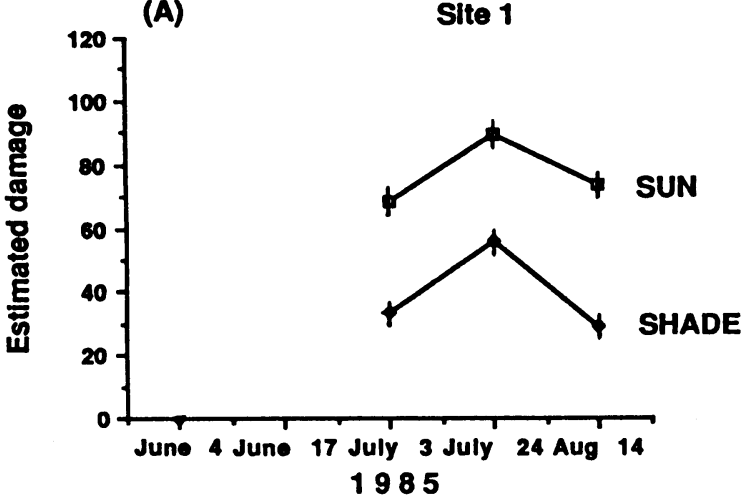

(C)

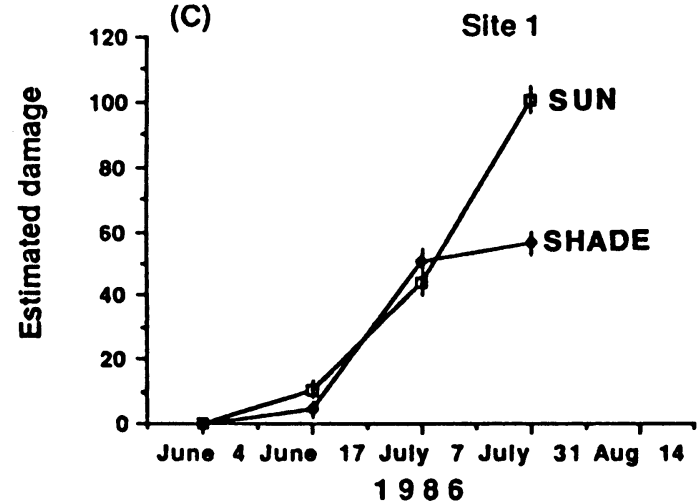

(B)

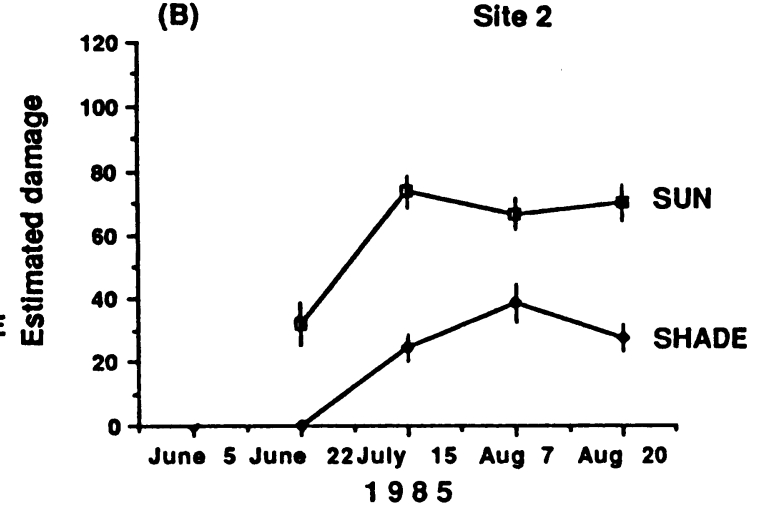

(D)

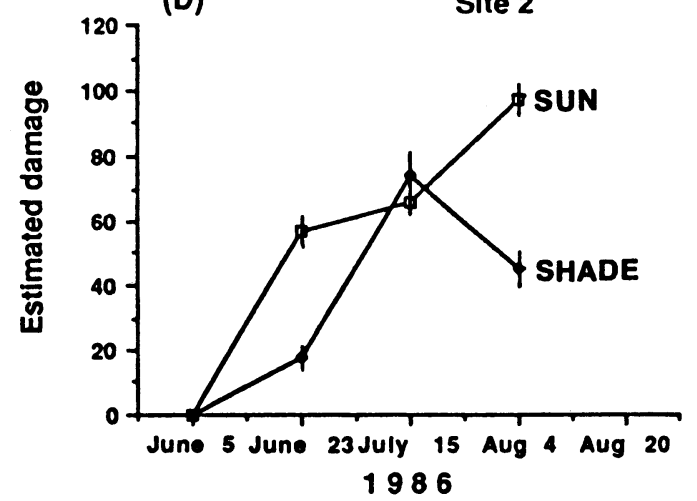

Fig. 2. Estimated amount of leaf-mining damage to C. cordifolia, measured as the area $\left(\mathrm{mm}^{2}\right)$ mined per leaf in sun-exposed versus shaded habitats in 1985 and 1986. (A) and (C), Site 1; (B) and (D), Site 2. Open squares ( $\square$ ), sun; closed diamonds $(\diamond)$, shade. Vertical lines are standard error bars. Values for dead and missing leaves in the last two sampling periods were estimated; the estimate used the probabilities of a leaf in that position being mined and of the mean area mined for a leaf in that position, using data from the previous sampling period. Differences between the means on the final sampling dates at both sites in both years are significant (ANOVA on square-root transformed values, $P<0.05$ ).

relative to its potential distribution across the sunshade ecotone (Louda in press).

Our results are consistent with those obtained for several other species of leaf miners. For example, Faeth et al. (1981), working with lepidopteran and coleopteran leaf miners on oak trees, also observed higher densities on sun-exposed leaves than on shaded leaves. This same pattern also occurred with a dipteran leaf miner on bracken fern (MacGarvin et al. 1986). However, other leaf-mining species are more abundant in shaded habitats (MacGarvin et al. 1986).

Within-Plant Patterns. Most of the leaves mined were on the lower two-thirds of stems (Fig. 3A$D)$. The distribution of leaf mining within ramets was generally similar between sun and shade habitats at both sites in both years (Fig. 3). It is likely that this within-plant distribution reflects differential attractiveness to the female (Chew 1977). Differences in secondary compound concentrations may be involved, at least in explaining the avoidance of very young, upper-position leaves, for these leaves have the highest concentrations of glucosi- nolates (Louda \& Rodman 1983a). Plant phenology may also be important (Collinge 1987), because the lower leaves are the first available and are present at the time of oviposition. Many lower leaves die before the average leaf miner completes development (S.K.C., unpublished data), but leaf miners readily move up the stem to intact leaves, where they form new "secondary" mines (Collinge 1987).

There are at least four hypotheses to explain the higher leaf-miner damage on bittercress plants in the sun. First, ovipositing females could prefer sunny habitats to shaded ones, possibly because of differences in temperature critical to thermoregulation. Higher damage in the sun would then reflect greater numbers of flies and frequency of oviposition there. This hypothesis is supported by observed early-season densities of adults in 1986, which were higher in sun than in shade (Collinge 1987).

Second, earlier snow melt in sun-exposed areas could result in faster growth and development of plants in the sun, with plant availability in the sun corresponding more closely to fly oviposition than the slightly later emergence of shade plants (Coll- 

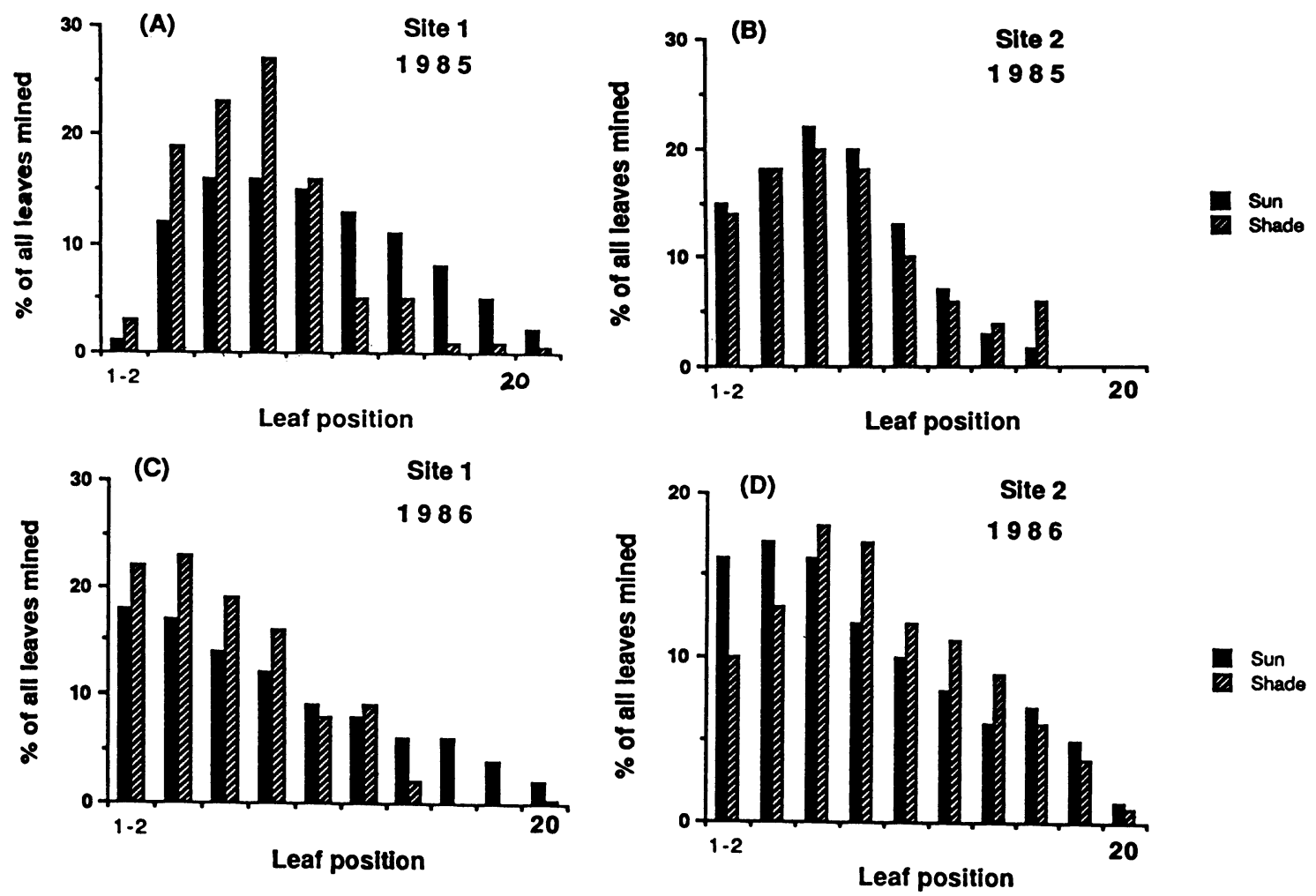

Fig. 3. Distribution of leaf mining on stems of Cardamine cordifolia by leaf position in 1985 and 1986. (A) and (C), Site 1; (B) and (D), Site 2. Shaded bars, sun; cross-hatched bars, shade. Value plotted is the proportion of the total leaves mined that were in each leaf position class. 1-2, the first two leaves on the stem, starting at the bottom; 3-4, the next two leaves, etc. All distributions (sun and shade, both sites and years) deviated significantly from a uniform distribution $\left(\chi^{2}\right.$ test, $\left.P<0.05\right)$.

inge 1987). Female drosophilids oviposit equally on bittercress clones transplanted from sun to shaded areas and those left in the sun (Collinge 1987). This evidence supports the hypothesis that the coincidence in timing of plant emergence in the sun and fly oviposition is a critical factor underlying the pattern of larval damage.

Third, slight differences in plant nutritive quality detectable to the ovipositing female may cause her to choose plants in the sun over plants in the shade for oviposition sites. Slightly higher concentrations of soluble carbohydrates but slightly lower concentrations of total and soluble nitrogen in sun leaves early in June (Table 1) suggest that if the hypothesis is correct, females prefer to lay eggs on leaves containing slightly higher levels of soluble carbohydrates. It may be that the adult is actually feeding before oviposition. Evidence from a lepidopteran herbivore shows that carbohydrate intake by the adult female increases longevity, body weight maintenance, and egg production (Murphy et al. 1983). It is likely that this factor may contribute to the first two hypotheses to produce the pattern of leaf mining on bittercress plants between sun and adjacent shade habitats.

Finally, plants in the sun may have a higher probability or frequency of water deficit stress, and this stress may increase their attractiveness to this herbivore. In other situations where the probability of water stress increases, such as the dry end of a soil moisture gradient, total insect damage to bittercress increases (Louda \& Rodman 1983b, Louda in press). An experimental test of stress in bittercress vulnerability to insect herbivores conducted in the shade habitat showed that stressed ramets had significantly more insect damage than unmanipulated control plants (Louda 1986). When bittercress plants are stressed by root-cutting, the amount and frequency of leaf mining increase, probably because of increases in soluble nitrogen and soluble carbohydrate compounds in the leaves (unpublished data).

\section{Acknowledgment}

We thank M. A. Bishop, D. Bouska, L. L. Collinge, J. Gyhra, J. Holdren, and J. T. Smith for enthusiastic help in the field; J. Stratton for grinding leaf samples; C. D. Langefeld, W. Stroup, and J. A. Wilson for help with data analysis; R. S. de la Motte, R. L. Pardy, G. Sarath, and F. W. Wagner for asssistance in amino acid analysis; B. C. Ratcliffe and G. C. Steyskal for entomological advice; $L$. S. Vescio for help with graphics; the staff of the 
Rocky Mountain Biological Laboratory (RMBL) for logistical support; and K. H. Keeler, M. V. Price, N. M. Waser, and the graduate student groups at the University of Nebraska-Lincoln and RMBL for stimulating discussion. D. Grimaldi (American Museum of Natural History) kindly identified our specimens of Scaptomyza nigrita. S. H. Faeth, A. Joern, R. L. Pardy, and an anonymous reviewer provided helpful suggestions on the manuscript. Generous support was provided by National Science Foundation Grants DEB82-07955 and BSR8405625 (to S.M.L.), a Sigma Xi Grant-in-Aid (to S.K.C.), the L. B. and E. R. Walker Award and the Jessie Lee Award (to S.K.C.) from the University of Nebraska School of Biological Sciences, and a graduate student scholarship (to S.K.C.) from RMBL.

\section{References Cited}

Association of Official Analytical Chemists. 1975. Methods of analysis, 12th ed. Arlington, Va.

Atkins, C. A. \& D. T. Canvin. 1971. Photosynthesis and $\mathrm{CO}_{2}$ evolution by leaf discs: gas exchange, extraction, and ion exchange fractionation of ${ }^{14} \mathrm{C}-\mathrm{la}-$ beled photosynthetic products. Can. J. Bot. 49: 12251234.

Bursell, E. 1974. Environmental aspects-temperature, pp. 1-36. In M. Rockstein [ed.], The physiology of Insecta, 2nd ed. Academic, New York.

Bultman, T. L. \& S. H. Faeth. 1988. Abundance and mortality of leaf miners on artificially shaded emory oak. Ecol. Entomol. 13: 131-142.

Chapman, R. F. 1982. The insects: structure and function, 3rd ed. Harvard University Press, Cambridge, Mass.

Chew, F. S. 1977. Coevolution of pierid butterflies and their cruciferous foodplants. II. The distribution of eggs on potential foodplants. Evolution 31: 568579.

Clark, K. V. 1967. Insects and temperature, pp. 293352. In A. H. Rose [ed.], Thermobiology. Academic, New York.

Coley, P. D. 1983. Intraspecific variation in herbivory on two tropical tree species. Ecology 64: 426-433.

Collinge, S. K. 1987. Leaf miner/bittercress interaction: experimental evaluation of a spatial pattern of resource use. M.S. thesis, University of Nebraska, Lincoln.

Condrashoff, S. F. 1964. Bionomics of the aspen leaf miner, Phyllocnistis populiella Cham. (Lepidoptera: Gracillariidae). Can. Entomol. 96: 857-875.

Conner, E. F., S. H. Faeth \& D. Simberloff. 1983 Leafminers on oak: the role of immigration and in situ reproductive recruitment. Ecology 64: 191-204.

Crawley, M. J. 1983. Herbivory: the dynamics of animal-plant interactions. University of California, Berkeley.

Denno, R. F. \& M. S. McClure [eds.]. 1983. Variable plants and herbivores in natural and managed systems. Academic, New York.

Dureseau, L., Jr., \& D. Jeandel. 1977. Alfalfa blotch leafminer (Diptera: Agromyzidae) laboratory studies of biology in Europe. Proc. Entomol. Soc. Wash. 79: 259-265.

Faeth, S. H. 1985. Host leaf selection by leaf miners: interactions among three trophic levels. Ecology 66: 870-875.

Faeth, S. H., S. Mopper \& D. Simberloff. 1981. Abundances and diversity of leaf-mining insects on three oak host species: effects of host plant phenology and nitrogen content of leaves. Oikos 37: 238-251.

Harper, J. L. 1969. The role of predation in vegetational diversity. Brookhaven Symp. Biol. 22: 48-62.

Harrington, H. D. 1954. Manual of the plants of Colorado. Sage Books, Denver, Colo.

Hering, E. M. 1951. Biology of the leaf miners. Junk, The Hague.

Holaday, A. S. \& R. Chollet. 1983. Photosynthetic/ photorespiratory carbon metabolism in the $\mathrm{C}_{3}-\mathrm{C}_{4}$ intermediate species, Moricandia arvensis and Panicum milioides. Plant Physiol. 73: 740-745.

Huffaker, C. B. \& C. E. Kennett. 1959. A ten year study of vegetational changes associated with biological control of Klamath weed. J. Range Mgmt. 12: 69-82.

Jones, V. P., M. P. Parella \& D. R. Hodel. 1986. Biological control of leaf miners in greenhouse chrysanthemums. Calif. Agric. 40(1-2): 10-12.

Langenheim, J. H. 1955. Flora of the Crested Butte Quadrangle, Colorado. Mandroño 13: 64-78.

1962. Vegetation and environmental patterns in the Crested Butte Area, Gunnison County, Colorado. Ecol. Monogr. 32: 249-285.

Larsson, S., A. Wiren, L. Lundgren \& T. Ericsson. 1986. Effects of light and nutrient stress on leaf phenolic chemistry in Salix dasyclados and susceptibility to Galerucella lineola (Coleoptera). Oikos 47: 205-210.

Louda, S. M. 1984. Herbivore effect on stature, fruiting, and leaf dynamics of a native crucifer. Ecology 65: 1379-1386.

1986. Insect herbivory in response to root cutting and flooding stress on a native crucifer under field conditions. Acta Oecol., Oecol. General 7: 37-53.

In press. Insect pests and plant stress as considerations for revegetation of disturbed ecosystems, chapter 13 . In J. Cairns [ed.], Rehabilitation of damaged ecosystems. CRC Press, Boca Raton, Fla.

Louda, S. M. \& J. E. Rodman. 1983a. Ecological patterns in the glucosinolate content of a native mustard, Cardamine cordifolia, in the Rocky Mountains. J. Chem. Ecol. 9: 397-421.

1983b. Concentration of glucosinolates in relation to habitat and insect herbivory for the native crucifer Cardamine cordifolia. Biochem. Syst. Ecol. 11: 199207.

Louda, S. M., M. A. Farris \& M. J. Blua. 1987. Variation in methylglucosinolate and insect damage to Cleome serrulata (Capparaceae) along a natural soil moisture gradient. J. Chem. Ecol. 13: 569-581.

MacGarvin, M., J. H. Lawton \& P. A. Heads. 1986. The herbivorous insect communities of open and woodland bracken: observations, experiments and habitat manipulations. Oikos 47: 135-148.

Mattson, W. J., Jr. 1980. Herbivory in relation to plant nitrogen content. Annu. Rev. Ecol. Syst. 11: 119-161.

Miller, P. F. 1973. The biology of some Phyllonorycter species (Lepidoptera: Gracillariidae) mining leaves of oak and beech. J. Nat. Hist. 7: 391-409.

Minchinton, I., J. Sang, D. Burke \& R. J. W. Truscott. 1982. Separation of desulphoglucosinolates by reversed-phase high-performance liquid chromatography. J. Chromatogr. 247: 141-148.

Mitchell, R. 1975. The evolution of oviposition tactics in the bean weevil, Callosobruchus maculatus (F.). Ecology 56: 696-702.

Mooney, H. A. \& C. Chu. 1974. Seasonal carbon al- 
location in Heteromeles arbutifolia, a California evergreen shrub. Oecologia (Berl.) 14: 295-306.

Moore, S. \& W. H. Stein. 1954. A modified ninhydrin reagent for the photometric determination of amino. acids and related compounds. J. Biol. Chem. 211: 907-913.

Murphy, D. D., A. E. Launer \& P. R. Ehrlich. 1983 The role of adult feeding in egg production and population dynamics of the checkerspot butterfly $E \mathbf{E}$ phydryas editha. Oecologia (Berl.) 56: 257-263.

Prestidge, R. A. \& S. MeNeill. 1983. Auchenorrhyncha-host plant interactions: leafhoppers and grasses. Ecol. Entomol. 8: 331-339.

Quade, D. 1966. On analysis of variance for the $k$-sample problem. Ann. Math. Stat. 37: 1747-1758.

Rausher, M. D. 1979. Larval habitat suitability and oviposition preference in three related butterflies. Ecology 60: 503-511.

Rodman, J. E. 1978. Glucosinolates: methods of analysis and some chemosystematic problems. Bull. Phytochem. Soc. 11: 6-31.

Rosenthal, G. A. \& D. H. Janzen [eds.]. 1979. Herbivores: their interaction with secondary plant metabolites. Academic, New York.

SAS Institute. 1985. SAS user's guide: statistics. SAS Institute, Cary, N.C.

Smith, D. 1969. Removing and analyzing total nonstructural carbohydrates from plant tissue. Research Department, University of Wisconsin College of Agriculture and Life Sciences, Madison.

University of California Statewide IPM Project. 1985. Integrated pest management for cole crops and lettuce. University of California Agricultural and Natural Sciences Publication 3307. Oakland, Calif.

White, T. C. R. 1969. An index to measure weatherinduced stress of trees associated with outbreaks of psyllids in Australia. Ecology 50: 905-909.
1970. Some aspects of the life history, host selection, dispersal, and oviposition of adult Cardiaspina densitexta (Homoptera: Psyllidae). Aust. J. Zool 18: 105117.

1974. A hypothesis to explain outbreaks of looper caterpillars, with special reference to populations of Selidosema sauvis in a plantation of Pinus radiata in New Zealand. Oecologia (Berl.) 16: 279-301.

1976. Weather, food and plagues of locusts. Oecologia (Berl.) 22: 119-134.

1978. The importance of a relative shortage of food in animal ecology. Oecologia (Berl.) 33: 71-86.

1984. The abundance of invertebrate herbivores in relation to the availability of nitrogen in stressed food plants. Oecologia (Berl.) 63: 90-105.

Whitfield, G. H., R. I. Carruthers, E. P. Lampert \& D. L. Haynes. 1985. Spatial and temporal distribution of plant damage caused by the onion maggot (Diptera: Anthomyiidae). Environ. Entomol. 14: 262-266.

Winer, B. J. 1971. Statistical principles in experimental design, 2nd ed. McGraw-Hill, New York.

Wiren, A. \& S. Larsson. 1984. Preferences of insects for different willow clones: a case study with Galerucella lineola (Col., Chrysomelidae), pp. 383-389. In $\mathrm{K}$. Perttu [ed.], Ecology and management of forest biomass production systems. Department of Ecology and Environmental Research, Swedish University of Agricultural Sciences Report.

Wolfson, J. L. 1982. Developmental responses of Pieris rapae and Spodoptera eridania to environmentally induced variation in Brassica nigra. Environ. Entomol. 11: 207-213.

Received for publication 24 June 1987; accepted 18 March 1988. 